\title{
ІСТОРИЧНІ ПЕРЕДУМОВИ ВИНИКНЕННЯ Й РОЗВИТКУ ДУАЛЬНОÏ СИСТЕМИ ПРОФЕСІЙНОЇ ОСВІТИ НІМЕЧЧИНИ
}

I. Д. Глазкова

\author{
HISTORICAL PREREQUISITES OF DUAL TRAINING SYSTEM \\ FOUNDATION AND DEVELOPMENT IN VOCATIONAL EDUCATION \\ OF GERMANY
}

\section{Hlazkova}

У статті розкрито актуальність упровадження в Україні дуальної форми професійного навчання та вказано на недостатність вітчизняного досвіду щодо цієї форми підготовки фахівців у закладах професійної (професійно-технічної), фахової передвищої та вищої освіти. У зв'язку з модернізацією змісту, зміною формату вітчизняної освіти в контексті загальноєвропейських тенденцій обгрунтовано об'єктивну потребу вивчення й узагальнення характерних ознак дуальної системи професійної освіти Німеччини, яка історично стала загальновизнаним лідером у світі. Аналізуючи історичні дослідження щодо становлення й розвитку дуальної системи освіти в Німеччині, автор зазначає недостатню кількість наукових праць, у яких розкривалися $\sigma$ історичні передумови виникнення й розвитку дуальної системи професійної освіти Німеччини і проводить ретроспективний аналіз переламних етапів розвитку дуальної системи професійної освіти, визначають їх значення в розвитку дуальної системи професійної освіти Німеччини. Виявлено, що організована система професійної освіти Німеччини у вигляді учнівської ремісничої практики закладена у період раннього Середньовіччя. Розвиток практичної складової дуальної системи розпочався наприкінці XII ст., а необхідність теоретичного навчання в учнівських майстернях, зумовлена стрімким культурним та технічним розвитком німецького суспільства, була усвідомлена впродовж XIII-XIV ст. Функціонування закладів професійної освіти Німеччини, які стали прообразом професійних шкіл, розпочалося в період XV-XVI ст. Масштабні реформи в системі професійної освіти Німеччини та становлення теоретичної складової дуальної системи навчання були спричинені індустріалізацією країни на початку XIX ст. Утвердження дуальної системи професійної освіти Німеччини пов'язано з прийняттям у 1897 році Закону «Про захист ремісників». Розроблення концепцій Г. Кершенштейнера, формування методичної складової освітнього процесу в закладах професійної освіти наприкінці XIX - початку XX ст. дало поштовх підприємствам на відкриття власних професійних шкіл. Надання доступу до професійної освіти в сфері промисловості жінкам, спричинене участю Німеччини у Першій світовій війні, що спричинила збагатило дуальну систему навчання елементами гендерної рівності. Возз'єднання Німеччини наприкінці XX ст. та економічне зростання початку XXI ст. стали основою активного розвитку дуальної форми професійного навчання. Огляд історичних фактів щодо зародження та розвитку 
дуальної системи навчання дозволив авторці виявити вісім передумов, що суттєво вплинули на виникнення і розвиток цієї форми професійної освіти в Німеччині.

Ключові слова: дуальна форма навчання, заклад професійної освіти, реформа освіти, теоретична складова професійної освіти, практична складова професійної освіти, ремесло, індустріалізація.

The article clarifies the relevance of implementing a dual form of professional training in Ukraine and point to the lack of national experience regarding such forms of specialists training like in technical and vocational training schools, higher educational institutions. Considering the content modernization and changing form of Ukrainian education in a context of common European trends, the objective needs to study and generalizing the characteristic features of the dual professional training system of Germany, which has historically become the world-renowned leader, has been substantiated. Analyzing the historical studies of the formation and development of the dual education system in Germany, the authors signify an insufficient number of scientific works, that reveal the historical prerequisites for the foundation and development of dual training system of professional education of Germany and conduct a retrospective analysis of the turning points in the dual system vocational education development and determine their significance. It became clear that the organized system of vocational education in Germany in the form of trainee craft practice was established in the early Middle Ages. The development of the practical component of the dual system, scientists attribute to the end of the XII century. The necessity for theoretical training in trainee workshops, due to the rapid cultural and technical development of German society, arose in the XIII-XIV centuries. The functioning of vocational education institutions in Germany, which became the prototype of vocational schools, began in the XV-XVI centuries. The major reforms in the system of vocational education in Germany and the formation of the theoretical component of the dual system of education were caused by the industrialization of the country in the early nineteenth century. The establishment of the dual system of vocational education in Germany, associated with the passage of the law "The Protection of Craftsmen" in 1897. The development of G. Kershensteiner's concepts, the formation of the methodical component of the educational process in vocational education institutions in the late XIX - early XX centuries, give an impulse to the factories to open their own vocational schools. Germany's participation in the First World War, which led to women's access to vocational education in the industry, enriched the dual system of education with elements of gender equality. German reunification in the late XX century and economic growth in the early XXI century became the basis for the active development of the dual form of vocational training. A review of the historical facts concerning the origin and development of the dual education system revealed eight prerequisites that significantly influenced the foundation of this form of vocational education in Germany.

Keywords: a dual form of vocational education; vocational education institution; education reform; theoretical component of vocational education; practical component of vocational education; craft; industrialization.

Постановка проблеми. Реформування освіти України в руслі сучасних загальноєвропейських тенденцій ставить перед українським суспільством завдання підготовки молоді, що має грунтуватися на кращих досягненнях світової та української педагогічної науки, історії та культури. 
Однією 3 важливих проблем реформування освіти, яка потребує якнайшвидшого розв'язання, $є$ недостатній рівень готовності багатьох випускників закладів вищої, фахової передвищої та професійної (професійно-технічної) освіти до самостійної професійної діяльності на первинних посадах, відповідних здобутій освіті.

Для вирішення вказаної проблеми, усунення основних недоліків традиційних форм і методів навчання, подолання розриву між теорією i практикою, освітою й виробництвом, підвищення якості підготовки фахівців із урахуванням вимог роботодавців у межах нових організаційновідмінних форм навчання в освітню систему України мають впроваджуватися елементи дуальної форми навчання, що відбивається у чинних нормативних документах: накази $\mathrm{MOH}$ «Професійна підготовка кваліфікованих робітників з використанням елементів дуальної системи навчання» на базі закладів професійно-технічної освіти» (2015 р.) та «Про впровадження елементів дуальної форми навчання у професійну підготовку кваліфікованих робітників» (2017р.); Закон України «Про освіту» (2017р.); Положення про дуальну форму здобуття освіти (2018 р.); Концепція підготовки фахівців за дуальною формою здобуття освіти (2019 р.); Концепція реалізації державної політики у сфері професійної (професійно-технічної) освіти «Сучасна професійна (професійно-технічна) освіта» на період до 2027 року» (2019 р.) та ін.

У зв'язку з недостатністю вітчизняної практики підготовки фахівців iз використанням дуальної форми навчання виникає необхідність звернутися до історичного досвіду інших країн, а саме Німеччини, яка має багатовікові традиції розвитку i реформування дуальної системи професійної освіти і наразі також відчуває на собі вплив загальносвітових процесів, пов'язаних 3 економічною глобалізацією. Дуальна система професійної освіти історично глибоко вкорінена в Німеччині і має широке визнання як в економіці, так і в суспільстві. Історія розвитку дуальної системи професійної освіти Німеччини є складовою історії світової педагогічної думки.

Аналіз основних досліджень і публікацій, в яких започатковано розв'язання даної проблеми. Більшість наявних у тематичному полі обраної проблеми наукових праць розкривають історичні аспекти становлення й розвитку системи професійної освіти Німеччини: Х. Даурова (2002), Г. Корнетов (2010), Ф. Паульсен (1908), М. Певзнер (1997), О. Піскунов (1963), С. Черкашин (2018), H. Abel $(1959,1964)$ та ін. 
У цих дослідженнях під різним кутом зору (філософським, політичним, педагогічним, структурним, змістовим, проблемним тощо) розглядаються процеси формування загальної системи професійної підготовки молоді від трудових та народних шкіл до закладів вищої освіти Німеччини. Такі дослідники, як Н. Абашкіна (1998), D. Euler (2013), С. Леу (2016), H. Reinisch (2001), N. Wollschläger \& É. Guggenheim (2004) та ін. здійснювали порівняльний аналіз систем професійного навчання Німеччини з іншими країнами Свропи, виокремлюючи характерні саме для Німеччини риси, однією з яких виступає дуальна система.

Разом із безперечною грунтовністю вказаних досліджень, питання розвитку дуальної форми професійного навчання висвітлюються в них побіжно, дотично до загальних історичних реалій. Більше уваги саме дуальній формі професійного навчання Німеччини приділено в доробках I. Бойчевської (2009), Г. Кершенштейнера (1911), Т. Козак (2011), Г. Федотової (2002), Н. Benner (1977), G. Bosch (2010), W.-D. Greinert (1998), F. Edner (2004), W.-D. Greinert (1998), H. Klein\&R. Zedler (1990), J. Munch (1994), A. Trifonov (2013), F. Wehrmeister (1995) та ін., хоча й вони не вирізняються системністю вивчення проблеми.

Так, організаційно-методичні особливості дуальної системи професійної освіти розкрито в працях Г. Кершенштейнера (1911), Г. Федотової (2002), H. Benner (1977), W.-D. Greinert (1998) та ін. F. Edner (2004), W.-D. Greinert (1998), H. Klein\&R. Zedler (1990), J. Munch (1994) та ін. оцінили загальносвітову роль Німеччини в розвитку цієї системи, визнавши, що вона виступає світовим лідером та входить до першої групи країн за рівнем кваліфікації кадрів, обгрунтувавши необхідність вивчення німецького досвіду дуальної освіти. І. Бойчевська (2009), Т. Козак (2011) висвітлили особливості організації й функціонування дуальної системи сучасної професійної освіти Німеччини, проблеми профільного навчання у професійних школах, тенденції їх реформування тощо.

Отже, наявні наразі наукові праці, які стосуються дуальної освіти Німеччини, мають частковий та аспектний характер, не конкретизуючи специфічних рис становлення цієї системи, зокрема тих чинників, що вплинули на їі розвиток.

Мета статті - виявити історичні передумови виникнення й розвитку дуальної системи професійної освіти Німеччини, що стали основою для формування сучасної ефективної форми професійної підготовки, загальновизнаної у світі. 
Виклад основного матеріалу. З'ясування історичних передумов виникнення дуальної системи професійної освіті Німеччини та виявлення тих чинників, що обумовлювали й коригували іï розвиток упродовж століть, $є$ важливим для визначення ключових орієнтирів та положень, які зробили цю систему однією з найефективніших серед аналогічних систем різних країн світу і які слід враховувати під час розвитку дуальної системи освіти в Україні. У Німеччині упродовж тривалого часу складалися відповідні передумови, що уможливили виникнення дуальної системи освіти в іiі сучасному вигляді, а також забезпечили життєздатність та ефективність цієї системи. Розглянемо їх докладніше.

Виникнення системи професійної освіти як організованої системи підготовки кваліфікованих фахівців у Німеччині було закладено у період раннього Середньовіччя, що знайшло відображення в історичних дослідженнях таких вітчизняних та іноземних науковців, як Н. Абашкіна (1998), J. Baumert (2008), Н. Benner (1977), Г. Федотова (2002), K. W. Stratmann (1967) та ін.

Дослідники Г. Федотова (2002), N. Wollschläger, É. F. Guggenheim (2004), W.-D. Greinert (1998), J. Munch (1994) та ін. зазначили, що в цей час у Німеччині професійна освіта мала ознаки впорядкованої i відрегульованої в правовому відношенні системи. Серед поширених професій були домашні ковалі, ливарники, кравці, шевці, теслі, столяри, золотих і срібних справ майстри та ін. Професійне навчання і виховання в умовах ремісничої діяльності здійснювалося на основі застосування методів наслідування, повторення та формування в учнів умінь і навичок виконання складних операцій (Munch, 1994). Навчання юнаків у майстра зводилось до передачі ремісницьких знань і навичок, якими володів сам майстер.

Широка представленість і функціональність учнівської ремісничої практики в Німеччині, на нашу думку, стала першою передумовою формування дуальної системи професійної освіти, а саме пї практичної складової. Хоча практичне навчання ремесел спостерігалося на той час і в інших країнах світу, саме в Німеччині воно набуло значних масштабів і заклало основи для виникнення в майбутньому учнівських майстерень, професійних цехів, гільдій тощо.

I. Хижняк та I. Глазкова (2019), D. Nicholas (1997), H. Fuhrmann (1986) та ін. дослідили формування практичної складової дуальної системи в період поширення товарно-грошових відносин у різних галузях 
економіки Німеччини (кінець XII ст.) та вказали, що становлення ремісників як самостійного промислового класу сприяло перетворенню міських кустарів на власників певних засобів виробництва, спричиняло розвиток цехів - своєрідних професійних організацій ремісників, які захищали інтереси своїх членів. Це сприяло розвитку міських ремесел та ремісничого учнівства.

Однак такий стан професійного навчання не міг задовольняти запити практики, наслідком чого стало виникнення учнівської майстерні. Г. Федотова (2002), N. Wollschläger \& É. F. Guggenheim (2004), W. Georg (1997) зазначали, що із середини XIII ст. навчання, наприклад, майстрів із будівництва, потребувало нових будівельних технологій і будівельної теорії. На великих будівельних майданчиках, наприклад, при зведенні кафедральних соборів, створювалися учнівські майстерні, де учні опановували елементарні теоретичні відомості з певної професії.

Активний культурний та технічний розвиток німецького суспільства у XIII-XIV ст. спричинив посилення вимог до майстрів та відповідне усвідомлення неможливості опанування ремесла лише практичним шляхом. Цей стало, на нашу думку, другою передумовою виникнення дуальної системи професійного навчання в Німеччині.

За висновками Н. Абашкіної (1998), N. Wollschlägerund É. F. Guggenheim (2004), D. Nicholas (1997), у період XV-XVI ст. почався процес економічної конкуренції між новоствореними європейськими державами. Професійна освіта в цих країнах стала показником економічної стабільності та державної незалежності. Почали функціонувати навчальні заклади, які здійснювали підготовку працівників різних рівнів кваліфікації.

Проте, незважаючи на потреби в теоретичній складовій професійного навчання, у цих закладах освіти здійснювалася переважно практична професійна підготовка фахівців, тоді як опануванню теорії відводилося дуже мало часу. Третьою передумовою, що суттєво вплинула на процес виникнення дуальної системи навчання в Німеччині, вважаємо початок у XV-XVI ст. економічної конкуренції між європейськими державами, яка надала поштовх заснуванню різних типів шкіл (академій), що стали прообразом майбутніх професійних шкіл: лицарських, художніх, ремісничих, бухгалтерських, будівельних, торговельних, гірничорудних тощо.

Зміна характеру праці під впливом індустріалізації та поява перших мануфактур знаменували собою якісно новий етап розвитку дуальної 
системи професійної освіти. Ремісниче учнівство перестало задовольняти потреби в кваліфікованих кадрах через невиправдано вузькі спеціалізації, низький рівень теоретичної підготовки. Крім того, професійне навчання в ремісництві цілком визначалося людиною, яка проводила навчання i знання якої не завжди відповідали рівню розвитку виробництва. Навчання, спрямоване на набуття теоретичних знань, стало найважливішим інструментом подолання подібної практики навчання. Відтак четвертою передумовою виникнення й розвитку дуальної системи професійної освіти в Німеччині вважаємо процеси виникнення мануфактур, широко представлені саме в цій країні. Індустріалізація стала причиною масштабних реформ у системі професійної освіти та виникнення професійних шкіл.

H. Reinisch (2001) відзначив, що на початку XIX ст., після відміни монополії ремісничих цехів на професійне навчання, рівень професійної підготовки молоді знизився. У зв’язку із цим виникла необхідність збереження основних позицій ремісництва у сфері професійної освіти. Німецькі економісти були стурбовані процесом руйнування ремісничих навичок, спричиненим поділом праці в індустріальному секторі виробництва, виступаючи за збереження ремісничих традицій i $і$ х впровадження в промисловість, мотивуючи це тим, що учнівство надає можливість розвивати в учнів різнобічні вміння i навички, позитивне ставлення до праці. Ідея учнівства була підтримана німецькими педагогами-реформаторами і отримала свій подальший розвиток у статусі ідеології німецьких педагогів професійної освіти ХХ ст. (Певзнер, 1997; Пискунов, 1963; Abel, 1959; Abel, 1964; Eppe, 1983).

Ілюстрацією тогочасного економічного відставання Німеччини стала доповідь Ф. Рело, директора Берлінської ремісничої академії i рейхскомісара, на Всесвітній промисловій виставці 1876 р. у Філадельфії. У своєму звіті з Америки він писав, що «німецькі вироби оцінюються на виставці як дешеві і погані» (Stratmann, 1967).

У відповідь на ці виклики у ХІХ ст. на теренах сучасної Німеччини вживалися заходи щодо скасування цехових статутів i введення Положення про свободу ремесел, що спричинило інтенсивний розвиток мануфактур і фабрик як промислових підприємств, де виробничі майстри почали використовувати досвід ремісничого професійного навчання для фахової підготовки кваліфікованих робітників у різних промислових галузях (Munch, 1994). В останній чверті ХІХ ст. Німеччина перетворилася 
на другу індустріальну державу світу, яка почала виробляти машини за допомогою машин (Паульсен, 1908). Так, з 1878 р. розпочинається період реформ у житті німецького суспільства, зокрема, оновлюється законодавство, що регулює господарський уклад Німеччини. Як наслідок, у 1897 р. з'являється Закон «Про захист ремісників». Власне, із цієї дати зазвичай ведуть відлік історії створення типово німецької моделі професійної освіти - дуальної системи.

Отже, n'ятою передумовою виникнення в Німеччині дуальної системи освіти визначаємо економічне відставання Німеччини у середині XIX ст. та промисловий переворот кінця XIX - початку XX ст., що спричинили численні спроби модернізації системи професійної підготовки робітничої молоді. Зокрема, виникли окремі заклади професійної освіти та отримали розвиток ідеї ідеологічного виховання молоді в професійних школах.

У 90-х рр. ХІХ ст. виробнича галузь Німеччини відчула дефіцит кваліфікованих робітничих кадрів. Ремісничі майстерні не встигали задовольняти зростаючий попит на учнів у сферах виробництва. У зв’язку iз цим підприємства почали відкривати власні школи професійного навчання, які поєднували працю учня на виробництві та набуття робочих спеціальностей у школі (Benner, 1977).

Починаючи 31896 р., німецька професійна школа почала реформи в контексті вимог промисловості, ініціатором яких став Г. Кершенштейнер, який стверджував, що головним завданням народної школи є загальна трудова підготовка. Дослідник реформував систему освіти відповідно до свого бачення: школи були оснащені власними майстернями та лабораторіями, шкільними садами, шкільними кухнями, акваріумами, залами для креслення і малювання та ін. (Кершенштейнер, 1911). Завдання професійної школи були розширені, до навчальних планів були включені нові предмети для «політичної освіти» учнів, такі як «Суспільствознавство». Г. Кершенштейнер сформував теоретичну концепцію професійної освіти, визначивши освітньо-теоретичні завдання професійної школи у вихованні в робітників громадянських якостей на робочому місці (Klein\&Zedler, 1990).

Таким чином, шостою передумовою виникнення дуальної системи професійної освіти Німеччини визначаємо початок наукового дослідження процесів професійної освіти на теоретичному та практичному рівнях наприкінці XIX - початку XX ст., зокрема, розроблення концепцій 
Г. Кершенштейнера, формування методичної складової освітнього процесу в закладах професійної освіти: інтеграція в навчальних планах загальноосвітніх та професійних дисциплін, визначення норм часу, місця навчання (школа чи підприємство) тощо.

Надалі Німеччина прагнула до політичного й економічного панування в Свропі і, включившись у боротьбу за колонії, бажала переділу на свою користь колоніальних володінь Англії, Франції, Бельгії, Нідерландів i Португалії, які до цього часу були найбільшими колоніальними імперіями світу. Політична позиція, яку можна охарактеризувати фразою рейхканцлера Бюло про боротьбу за «місце під сонцем» («Platzander Sonne»), вимагала повної ідеологізації, з-поміж іншого, і професійної освіти, яка була націлена на виховання у молоді ідеологічного переконання в тому, що Німеччина - країна великої культури, великої науки 3 великим минулим, великим теперішнім i великим майбутнім.

Освітня система була цілком і повністю підпорядкована державі. Ця обставина відповідала завданню такого виховання людини, яке давало «на виході» тип конформіста, лояльного громадянина, патріота-націоналіста, головне ж - вмілого, старанного робітника. Ідеологія професійної освіти кайзерівської Німеччини полягала в потребі підготувати робітничі сили, стримуючи при цьому вільний розвиток вищих здібностей особистості: думати, але не надто інтенсивно; знати, але тільки корисне для роботи; вміти підкорятися, не розмірковуючи (Корнетов, 2010).

У період Першої світової війни (1914-1919 рр.) система професійної освіти Німеччини зазнала певних перетворень. Насамперед це торкнулося професійної освіти дівчат та молодих жінок, адже держава потребувала їхньої підвищеної професійної підготовленості не тільки у «типовій» професійній сфері текстильної, швейної промисловості, сферах освіти та охорони здоров'я, а насамперед у промисловому виробництві. Жінки мали замінити чоловіків, які воювали на фронті (Кривець\&Мартинов, 2010).

Слід зазначити, що перша дівчина закінчила середню школу в Пруссії у 1896 р., а вже у 1908 p. середні школи для дівчат були інтегровані в загальноосвітню систему. Відтоді жінки $з$ дипломом про середню освіту могли також навчатися в системі професійної освіти. У 1919 р. у зв’язку з демобілізацією солдатів, жінки змушені були звільняти робочі та навчальні місця на користь чоловіків. Тим не менш, зайнятість молодих жінок у професійній освіті зростала до початку Великої депресії 
та нацистської диктатури $30-x$ років XX ст. Знову робота жінок буде масово повторно використана на заводах під час Другої світової війни (Кривець\&Мартинов, 2010).

Наслідки Першої світової війни істотно загальмували розвиток професійної освіти, оскільки Німеччина пережила важку економічну i соціальну кризу. Зміни в професійній освіті відбулися здебільшого в перші роки по закінченню Першої світової війни (1918-1922рр.) і проявилися в посиленні централізації управління професійною освітою. Ринок праці потребував не просто «універсального робітника», а освіченої людини 3 глибокими загальними знаннями (Кривець\&Мартинов, 2010).

Отже, сьомою передумовою виникнення й розвитку дуальної системи професійної освіти визначаємо надання доступу до професійної освіти у сфері промисловості жінкам, спричинене участю Німеччини у Першій світовій війні, що збагатило дуальну систему навчання елементами гендерної рівності.

У 1927 р. центральні ремісничі асоціації Німеччини об'єднались у Робочий комітет з професійного навчання (AfB) - орган планування i управління професійним навчанням на виробництві, діяльність якого сприяла розвитку методичних засад професійної підготовки молоді. (Greinert, 1998). Однак 1933 р. до влади прийшли нацисти на чолі 3 А. Гітлером, і нацистська ідеологія та підготовка молоді до воєнних дій унеможливили розвиток професійної освіти. Взаємозв'язок та координація дій підприємств із професійними школами з метою узгодження навчальних програм почали відновлюватися лише із 1945 р., у результаті чого на виробництві стала домінувати практична освіта, а навчання в професійній школі було орієнтовано на засвоєння теоретичних відомостей щодо технологій виробництва (Trifonov, 2013; Herkner, 2013).

Надалі розвиток дуальної системи професійної освіти відбувався в умовах поділу єдиної держави на дві з різним суспільно-політичним ладом: Федеративну Республіку Німеччина (ФРН) та Німецьку Демократичну Республіку (НДР). Необхідність відновлення економіки країни в повоєнні роки, низький рівень науково-технічної бази закладів освіти, вимоги, які ставилися до загальноосвітньої та професійної підготовки робітничих кадрів, призвели до змін у системі професійної освіти. Так, у ФРН було відновлено дуальну систему професійної освіти та без змін прийнято організаційну структуру навчальних закладів Веймарської Республіки (Даурова, 2002). 
Професійна освіта НДР була прерогативою та завданням держави (Wehrmeister, 1995). Теоретична підготовка учнів невеликих підприємств проводилась в муніципальних (diekommunale Berufsschule) та заводських професійних школах (die Betriebsberufsschule), які були основною формою підготовки кваліфікованих робітників у НДР і стали альтернативою дуальній системі професійної освіти (Wehrmeister, 2005).

Об'єднання ФРН та НДР, економічна криза 1990-х рр., приватизація державних підприємств, що брали участь у дуальному навчанні, процес трансформації заводських шкіл у систему професійної освіти ФРН, нестача та малий вибір навчальних місць, безробіття призвели до кризи дуальної системи професійної освіти, яка тривала з 1990 по 2004 pp. (Klemm, 2011). Трансформація системи професійної освіти НДР в дуальну систему професійної освіти ФРН відбувалася важко. Причиною була суттєва відмінність систем освіти, однак спільні прагнення освітян та підприємців до економічного зростання Німеччини, а також емоційне піднесення, що панувало в німецькому суспільстві після возз'єднання країни, сприяли розвитку теоретичних та практичних засад дуального навчання на теоретичному, практичному та законодавчому рівнях.

Від 2005 р. і дотепер дуальна система професійної освіти Німеччини розвивається й модернізується, характеризуючись значним зростанням кількості закладів професійної освіти, які використовують дуальну форму навчання, посиленням теоретичної бази професійної освіти, збільшенням кількості наукових досліджень ефективних шляхів розвитку системи дуальної освіти в Німеччині та ін. Відтак восьмою передумовою виникнення й розвитку дуальної системи професійної освіти Німеччини стало возз'єднання країни наприкінці XX ст. та подальше об'єднання зусиль освітян, підприємців, науковців, уряду в активному відпрацюванні ефективних форм професійного навчання як на виробництві, так і в професійній школі.

Висновки. Огляд історичних фактів щодо зародження та розвитку дуальної системи навчання дозволив виявити вісім передумов, що суттєво вплинули на виникнення цієї форми професійної освіти саме в Німеччині:

1. Активний розвиток учнівської ремісничої практики у Німеччині XII-XIII ст., що стало підгрунтям для виникнення учнівських майстерень, професійних цехів, гільдій.

2. Культурний та технічний розвиток німецького суспільства у XIIIXIV ст., який спричинив посилення вимог до майстрів та відповідне 
усвідомлення неможливості опанування ремесла лише практичним шляхом.

3. Формування в XV-XVI ст. європейських держав та економічна конкуренція між ними, заснування різних типів шкіл (академій), що стали прообразом майбутніх професійних шкіл: лицарських, художніх, ремісничих, бухгалтерських, будівельних, торговельних, гірничорудних та iH.

4. Активний розвиток мануфактур та початок індустріалізації в країні у XVII-XVIII ст., масштабні реформи в системі професійної освіти, виникнення професійних шкіл.

5. Економічне відставання Німеччини у середині ХІХ ст. та промисловий переворот кінця XIX - початку XX ст., відкриття окремих закладів професійної освіти, розвиток ідей ідеологічного виховання молоді в професійних школах.

6. Наукові дослідження процесів професійної освіти на теоретичному та практичному рівнях наприкінці XIX - початку XX ст. (концепція Г. Кершенштейнера), формування методичної складової освітнього процесу в закладах професійної освіти: інтеграція в навчальних планах загальноосвітніх та професійних дисциплін, визначення норм часу, місця навчання (професійна школа чи виробництво) тощо.

7. Надання доступу до професійної освіти у сфері промисловості жінкам, спричинене участю Німеччини у Першій світовій війні, внесення до дуальної системи навчання елементів гендерної рівності.

8. Возз'єднання країни наприкінці ХX ст., емоційне піднесення суспільства, паралельний розвиток дуальної системи професійної освіти на теоретичному, практичному та законодавчому рівнях.

Перспективи подальших досліджень проблеми вбачаємо в порівняльно-педагогічному вивченні національних рамок кваліфікацій i державних класифікаторів професій; теоретичному обгрунтуванні відбору і структурування змісту навчального матеріалу для підготовки кваліфікованих робітників, фахових молодших бакалаврів за дуальною формою здобуття освіти, принципів соціального партнерства у Німеччині та вивчення сучасних підходів до модернізації професійної освіти в умовах європейської інтеграції. 


\section{СПИСОК ЛІТЕРАТУРИ}

Абашкіна, Н. В. (1998). Принципи розвитку професійної освіти в Німеччині. Київ, Україна: Вища школа.

Бойчевська, I. (2009). Роль системи дуальної освіти у професійній підготовці молоді у Німеччині. Порівняльно-педагогічні студї̈, 2. 68-74.

Даурова, Х. М. (2002). Интеграчия системы образования бывшей ГДР в общегерманскую систему. (Дис. канд. пед. наук). Майкоп: Адыгейский государственный университет.

Кершенштейнер, Г. (1911). Основные вопросы школьной организащии. СанктПетербург: Тип. т-ва И. Д. Сытина.

Козак, Т. (2011). Професійна підготовка старшокласників у закладах середньої освіти другого ступеня Німеччини. (Дис. канд. пед. наук). Тернопільський національний педагогічний університет імені Володимира Гнатюка, Тернопіль.

Корнетов, Г.Б. (Ред.). (2010). Педагогическое наследие прошлого: Развитие государственной системы народного образования в Германии (до 1933 года). Москва: АСОУ.

Кривець, Н. та Мартинов, А. (2010). Німеччина. У: Смолій, В.(Ред.). Енциклопедія історії Украӥни: Т. 7 (сс. 404-416). Київ: Наукова думка.

Леу, С. (2018). Учнівство в професійній освіті й навчанні країн європейського союзу. Професійна педагогіка, 12, 116-126. doi: https://doi.org/10.32835/2223-5752.2016.12.116-126.

Паульсен, Ф. (1908). Исторический очерк развития образования в Германии. Москва: Т-во И. Д. Сытина.

Певзнер, М. Н. (1997). Реформаторская педагогика Западной Европьл конща XIX начала XX века. (Дис. докт. пед. наук). Новгород: Новгородский государственный университет.

Пискунов, А. И. (1963). Теория и практика трудовой школь Германии (до Веймарской peсnублики). Москва: Академия педагогических наук СССР.

Федотова, Г. А. (2002). Развитие дуальной формы профессионального образования (onыm ФРГ и России). (Дис. докт. пед. наук). Москва: Институт развития профессионального образования.

Хижняк, I. та Глазкова, I. (2019). Становлення теоретичного та практичного компонентів дуальної системи освіти в Німеччині. Професіоналізм педагога: теоретичні й методичні аспекти, 9, 70-83. doi: https://doi.org/10.31865/2414-9292.9.2019.174538

Черкашин, С. (2020). Німецькі науково-дослідні університети в процесі конвергенції світової університетської освіти. Засоби навчальної та науково-дослідної роботи, 51, 7-19.

doi: https://doi.org/10.34142/2312-1548.2018.51.01

Abel, H. (1959). Die Berufsschule. Gestalt und Reform. Darmstadt: Carl Winter.

Abel, H. (1964). Grund-und Realformen der Lehrlingsausbildung im produzierenden Gewerbe. Braunschweig: Jahrbuch der Deutschen Gesellschaft fur Gewerbliches Bildungswesen. 
Benner, H. (1977). Der Ausbildungsberaf als berufspaedagogisches und bildungsoekonomisches Problem. Hannover.

Bosch, G. (2010). Zur Zukunft der dualen Berufsausbildung in Deutschland. Das duale Berufsbildungssystem in Deutschland. Verlag für Sozialwissenschaften. doi: https://doi.org/10.1007/978-3-531-92391-8_22.

Edner, F. (2004). Die Berufsausbildung im Dualen System. München: GRIN Verlag GmbH.

Eppe, H. (1983). Selbsthilfe und Interessenvertretung. Die sozial- und jugendpolitischen Bestrebungen der sozialdemokratischen Arbeiterjugendorganisation 1904-1933. Bonn: Sozialist. Jugend Deutschlands, Die Falken, Bundesvorstand Bonn Erschienen.

Euler, D. (2013). Das duale System in Deutschland - Vorbild für einen Transfer ins Ausland? Bertelsmann Stiftung. doi: https://doi.org/10.11586/2017021

Fuhrmann, H. (1986). Germany in the High Middle Ages c. 1050-1200. New York: Cambridge University Press.

Georg, W. (1997). Zwischen Tradition und Moderne: Berufsbildung im internationalen Vergleich. In: Arnold, R.; Dobischat R. et al. (eds.): Weiterungen der Berufspädagogik (ss. 153-166). Stuttgart: Steiner.

Greinert, W.-D. (1998). Das «deutsche System» der Berufsausbildung. Tradition, Organisation, Funktion. Baden-Baden: Nomos.

Herkner, V. (2013). Grundzüge der Genese und Entwicklung einer korporatistischen Ordnung von Ausbildungsberufe. Geschichte der Berufsbildung. BWP, 3, 16-19.

Klein, H. E., Zedler, R. (1990). Tendenzen dualer Berufsbildung in Europa. Bonn: Informationen zur beruflichen Bildung.

Klemm, K. (2011). Das Bildungssystem Deutschlands: Strukturen und Strukturreformen. In: Reinders H., Ditton H., Gräsel C., Gniewosz B. (eds) Empirische Bildungsforschung. VS Verlag für Sozialwissenschaften. doi: https://doi.org/10.1007/978-3-531-93015-2_13.

Munch, J. (1994). Das Berufsbildungssystem in der Bundesrepublik Deutschland. Luxemburg: Amt für Amtliche Veröff. der Europ. Gemeinschaften.

Nicholas, D. (1997). The Growth of the Medieval City: From Late Antiquity to the Early Fourteenth Century. London: Longman.

Reinisch, H. (2001). Zwischen Schule und Betrieb. Aspekte der historischen beruflicher Bildung in den Niederlanden und in Deutschland aus vergleichender Sicht. Berufsbildung, 32, 27-34.

Stratmann, K. W. (1967). Die Krise der Berufserziehung im 18 Jahrhundert als Ursprungsfeld padagogischen Denkens. A-Henn: Verlag Ratingen.

Trifonov, A. (2013). Das duale System der Berufsausbildung in Deutschland: Eine historischsystematische Analyse seiner Entwicklung von 1869 bis 1945. Hamburg, Deutschland: Diplomica Verlag.

Wehrmeister, F. (1995). Die Betriebsberufsschule $\quad$ - Hauptsäule des DDR Berufsbildungssystems. Die berufsbildende Schule, 47, 212-217. 
Wehrmeister, F. (2005). Betriebsberufsschulen in der ehemaligen DDR: Die Koordinierung der Berufsausbildung in der Kultusministerkonferenz. Die Koordinierung der Berufsausbildung in der Kultusministerkonferenz. (ss. 71-96). Bonn: KMK.

Wollschläger, N., Guggenheim É. F. (2004). A history of vocational education and training in Europe - From divergence to convergence. Vocational Training European Journal, 32, 6-17.

\section{REFERENCES}

Abashkina, N. V. (1998). Pryntsypy rozvytku profesiinoi osvity v Nimechchyni. [Principles of development of vocational education in Germany]. Kyiv, Ukraina: Vyshcha shkola. [in Ukrainian]

Boychevska, I. (2009). Rol sistemi dualnoyi osviti u profesiyniy pidgotovtsi molodi u nimechchini [The role of the dual education system in the training of young people in Germany]. Porivnyalno-pedagogichni studiyi [Comparative and pedagogical studies], 2, 68-74. [in Ukrainian]

Daurova, Kh. M. (2002). Integratsiya sistemy obrazovaniya byvshey GDR $v$ obshchegermanskuyu sistemu. (Dis. ...kand. ped. nauk). [Integration of the education system of the former GDR into the pan-German system. (Thesis for a Degree Candidate of Pedagogical Sciences)]. Maykop, Rossiyskaya federatsiya: Adygeyskiy gosudarstvennyy universitet. [in Russian]

Kershenshteyner, G. (1911). Osnovnye voprosy shkol'noy organizatsii. [Main issues of the school organization]. Sankt-Peterburg: Tip. t-va I.D. Sytina. [in Russian]

Kozak, T. (2011). Profesiyna pidgotovka starshoklasnikiv u zakladah serednoyi osviti drugogo stupenya Nimechchini [Vocational training of high school students in secondary schools of the second degree in Germany]. (Dis. kand. ped. nauk). Ternopilskiy natsionalniy pedagogichniy universitet imeni Volodimira Gnatyuka, Ternopil. [in Ukrainian]

Kornetov, G. B. $\quad$ (Red.). (2010). Pedagogicheskoe nasledie prishlogo: Razvitie gosudarstvennoy sistemy narodnogo obrazovaniya $v$ Germanii (do 1933 goda). [Pedagogical Heritage of the Income: Development of the State System of Public Education in Germany (until 1933)]. Moskva: ASOU. [in Russian]

Kryvets, N., Martynov, A. (2010). Nimechchyna [Germany]. U: Smolii, V. (Red.). Entsyklopediia istorii Ukrainy [Encyclopedia of the History of Ukraine]: T. 7. (ss. 404-416). Kyiv: Naukova dumka. [inUkrainian]

Leu, S. (2018). Uchnivstvo v profesijnij osviti j navchanni krayin yevropejs kogo soyuzu. [Participation in vocational education and training of the countries of the european union]. Profesijna pedagogika, (12), 116-126.

doi: https://doi.org/10.32835/2223-5752.2016.12.116-126 [in Ukrainian]

Paul'sen, F. (1908). Istoricheskiy ocherk razvitiya obrazovaniya v Germanii. [Historical essay on the development of education in Germany]. Moskva: T-vo I.D. Sytina. [in Russian]

Pevzner, M. N. (1997). Reformatorskaya pedagogika Zapadnoy Evropy kontsa XIX -nachala $X X$ veka. (Dis. dokt. ped. nauk). [Reform pedagogy of Western Europe in the late XIX early $X X$ centuries (Doctor's thesis)]. Novgorod, Rossiyskaya federatsiya: Novgorodskiy gosudarstvennyy universitet. [in Russian] 
Piskunov, A. I. (1963). Teoriya i praktika trudovoy shkoly Germanii (do Veymarskoy respubliki). [Theory and practice of the German labor school (before the Weimar Republic)]. Moskva, Rossiyskaya federatsiya: Akademii pedagogicheskikh nauk SSSR. [in Russian]

Fedotova, G. A. (2002). Razvitie dual'noy formy professional'nogo obrazovaniya (opyt FRG $i$ Rossii). (Dis. dokt. ped. nauk). [Development of dual form of professional education (experience of Germany and Russia) (Doctor's thesis)]. Moskva, Rossiyskaya federatsiya: Institut razvitiya professional'nogo obrazovaniya. [in Russian]

Khyzhniak, I., Hlazkova, I. (2019). Stanovlennia teoretychnoho ta praktychnoho komponentiv dualnoi systemy osvity $\mathrm{v}$ Nimechchyni. [The development of the theoretical and practical components of the dual education system in Germany]. Profesionalizm pedahoha: teoretychni y metodychni aspekty, $9 . \quad 70-83$. doi: https://doi.org/10.31865/2414-9292.9.2019.174538. [in Ukrainian]

Cherkashyn, S. (2020). Nimetski naukovo-doslidni universytety v protsesi konverhentsii svitovoi universytetskoi osvity. [German research universities in the process of convergence of world university education]. Zasoby navchalnoi ta naukovo-doslidnoi roboty, $0(51), 7-19$.

doi: https://doi.org/10.34142/2312-1548.2018.51.01. [in Ukrainian]

Abel, H. (1959). Die Berufsschule. Gestalt und Reform. Darmstadt: Carl Winter.

Abel, H. (1964). Grund-und Realformen der Lehrlingsausbildung im produzierenden Gewerbe. Braunschweig: Jahrbuch der Deutschen Gesellschaft fur Gewerbliches Bildungswesen.

Benner, H. (1977). Der Ausbildungsberaf als berufspaedagogisches und bildungsoekonomisches Problem. Hannover.

Bosch, G. (2010). Zur Zukunft der dualen Berufsausbildung in Deutschland. Das duale Berufsbildungssystem in Deutschland. Verlag für Sozialwissenschaften.

doi: https://doi.org/10.1007/978-3-531-92391-8_2.

Edner, F. (2004). Die Berufsausbildung im Dualen System. Munchen: GRIN Verlag GmbH.

Eppe, H. (1983). Selbsthilfe und Interessenvertretung. Die sozial- und jugendpolitischen Bestrebungen der sozialdemokratischen Arbeiterjugendorganisation 1904-1933. Bonn: Sozialist. Jugend Deutschlands, Die Falken, Bundesvorstand Bonn Erschienen.

Euler, D. (2013). Das duale System in Deutschland - Vorbild fur einen Transfer ins Ausland? Bertelsmann Stiftung. doi: https://doi.org/10.11586/2017021.

Fuhrmann, H. (1986). Germany in the High Middle Ages c. 1050-1200. New York: Cambridge University Press.

Georg, W. (1997). Zwischen Tradition und Moderne: Berufsbildung im internationalen Vergleich. In: Arnold, R.; Dobischat R. et al. (eds.): Weiterungen der Berufspädagogik (ss. 153-166). Stuttgart: Steiner.

Greinert, W.-D. (1998). Das «deutsche System» der Berufsausbildung. Tradition, Organisation, Funktion. Baden-Baden: Nomos.

Herkner, V. (2013). Grundzyuge der Genese und Entwicklung einer korporatistischen Ordnung von Ausbildungsberufe. Geschichte der Berufsbildung. BWP, 3, 16-19. 
Klein, H. E., \& Zedler, R. (1990). Tendenzen dualer Berufsbildung in Europa. Bonn: Informationen zur beruflichen Bildung.

Klemm, K. (2011). Das Bildungssystem Deutschlands: Strukturen und Strukturreformen In: Reinders H., Ditton H., Gräsel C., Gniewosz B. (eds) Empirische Bildungsforschung. VS Verlag fur Sozialwissenschaften. doi: https://doi.org/10.1007/978-3-531-93015-2_13

Munch, J. (1994). Das Berufsbildungssystem in der Bundesrepublik Deutschland. Luxemburg: Amt für Amtliche Veryeff. der Europ. Gemeinschaften.

Nicholas, D. (1997). The Growth of the Medieval City: From Late Antiquity to the Early Fourteenth Century. London: Longman.

Reinisch, H. (2001). Zwischen Schule und Betrieb. Aspekte der historischen beruflicher Bildung in den Niederlanden und in Deutschland aus vergleichender Sicht. Berufsbildung. 32, $27-34$.

Stratmann, K. W. (1967). Die Krise der Berufserziehung im 18 Jahrhundert als Ursprungsfeld padagogischen Denkens. A-Henn Verlag Ratingen.

Trifonov, A. (2013). Das duale System der Berufsausbildung in Deutschland: Eine historischsystematische Analyse seiner Entwicklung von 1869 bis 1945. Hamburg, Deutschland: Diplomica Verlag.

Wehrmeister, F. (1995). Die Betriebsberufsschule $\quad-$ Hauptseyule des DDR Berufsbildungssystems. Die berufsbildende Schule. 47, 212-217.

Wehrmeister, F. (2005). Betriebsberufsschulen in der ehemaligen DDR: Die Koordinierung der Berufsausbildung in der Kultusministerkonferenz. Die Koordinierung der Berufsausbildung in der Kultusministerkonferenz. (ss. 71-96). Bonn: KMK.

Wollschleyger, N. Guggenheim É. F. (2004). A history of vocational education and training in Europe - From divergence to convergence. Vocational Training European Journal, 32, 6-17.

\section{Глазкова Ірина Дамирівна}

аспірант кафедри педагогіки і методики технологічної та професійної освіти ДВНЗ «Донбаський державний педагогічний університет»

вул. Генерала Батюка, 19, м. Слов'янськ, Донецька область, Україна, 84116

Тел. +38(066) 3644298

ORCID ID 0000-0002-4365-400X

e-mail: hlazkovaira@gmail.com

\section{Hlazkova Iryna}

PhDStudent of Department of Pedagogy and Methodology Technology and Vocational Education SHEI "Donbass State Pedagogical University"

H. Batiuka Str, Sloviansk, Donetsk region region, Ukraine 84116

Tel. +38(066) 3644298

ORCID ID 0000-0002-4365-400X

e-mail: hlazkovaira@gmail.com 